\title{
Notes on Brachymenium in Guyana with a new species from Mt. Ayanganna
}

\author{
Harold Robinson', G. Karen Golinski ${ }^{1,2}$ \\ I Department of Botany, MRC 166, Museum of Natural History, P.O. Box 37012, Smithsonian Institution, \\ Washington, DC, USA 2 Department of Botany, The University of British Columbia, Room 3200-6270 Uni- \\ versity Boulevard, Vancouver, BC, Canada
}

Corresponding author: Harold Robinson (robinsoh@si.edu)

Academic editor: Peter de Lange | Received 14 August 2019 | Accepted 30 June 2020 | Published 3 August 2020

Citation: Robinson H, Golinski GK (2020) Notes on Brachymenium in Guyana with a new species from Mt. Ayanganna. PhytoKeys 154: 11-17. https://doi.org/10.3897/phytokeys.154.39105

\begin{abstract}
A relative of the African species described by Brotherus as Bryum perspinidens, has been discovered in Guyana with erect capsules and a short inner peristome. The Guyana material is recognized as a new species, and both species are placed in the genus Brachymenium. The characteristics that distinquish the genus are discussed with reference to the Guyana specimens of Brachymenium speciosum.
\end{abstract}

\section{Keywords}

African relationship, Bryaceae, peristome, rostrate operculum

\section{Introduction}

Study of bryophyte collections obtained during the Smithsonian Biological Diversity of the Guianas project, has revealed a number of interesting species. Among these are two two collections of a bryaceous moss with capsules identifiable as a Brachymenium Schwaegr., Spec. Musc. Suppl. 2(1): 131. 1824, with a leaf that superficially matches the illustration of Bryum perspinidens Broth. in the Brotherus treatments in the two editions (1904 and 1925) of Engler and Prantl. The only problems were that the Brotherus illustration was of an African species named as a Bryum. The spiniform teeth of the leaf margins were nevertheless similar, and a relationship seemed to be involved. As for the generic placement, the Brotherus (1897) species was described from sterile material so that the placement in Bryum Hedw. lacked any real evidence. 
The relationship of Guyana Highland species to African species fits a pattern noted by Robinson (1965). In addition, there is ample material from Guyana of another species of Brachymenium, B. speciosum that is newly discussed and illustrated.

\section{Methods}

Specimens in this study were obtained during the Smithsonian Biological Diversity of the Guianas Program conducted over a period of years from 1985 to 2014 (Kelloff et al. 2019). The particular specimens of the new species involved in this study were collected during a separately funded trip conducted by M.D. Clark in 2001 that collected on Mt. Ayanganna. The bryophytes were deposited at the US National Herbarium awaiting identification. They have been in storage since that time.

A note with the specimens indicates that when they arrived in the US they were irradiated during the Anthrax scare of 2001.

\section{Results}

The South American material includes one species that seems to be distinct from others from the Western Hemisphere (see for example Allen 2002) and from the related African species.

\section{Brachymenium ayangannensis H.Rob. \& G.K.Golinski, sp. nov.}

Figure 1

Type. Guyana. Region: Potaro-Siparuni. Mt. Ayanganna, east face, plateau above second of four escarpments. $1380 \mathrm{~m}, 05^{\circ} 22.550^{\prime} \mathrm{N}, 059^{\circ} 58.350^{\prime} \mathrm{W}$. Scrub forest on sandstone and peat, with Clusia, Pagamea and Sphagnum. Epiphyte; sporophytes green. 17 June 2001. H.D. Clarke 9299, with R. Williams, C. Perry, E. Tripp \& J. Kelly (US).

Description. Stems up to $3 \mathrm{~cm}$ tall, leaves not closely spaced, rather firm in structure but contorted when dry and resistant to wetting. Costa percurrent into a long slender acumination, median cells narrowly oval, with firm walls showing slight porosity, mostly 80-100 $\mu \mathrm{m}$ long and ca. $30 \mu \mathrm{m}$ wide, without shorter quadrate cells at base, margin with numerous rows of linear pale cells forming a strong border, border with numerous cells projecting as spiniform teeth, such spiniform teeth extending onto apical acumination. Synoicous? Seta pale yellowish-red, ca. $17 \mathrm{~mm}$ long, smooth. Capsules erect, ca. $2 \mathrm{~mm}$ long, with short hypophysis, operculum short-rostrate, higher than wide. Outer peristome teeth reddish, rudimentary, ca. $80 \mu \mathrm{m}$ long, inner peristome a low pale membrane ca. $70 \mu \mathrm{m}$ without projecting segments or cilia. Calyptra not seen. Spores ca. $10 \mu \mathrm{m}$ in size.

Additional material. Guyana. Region: Potaro-Siparuni. Mt. Ayanganna, east face, area near camp at base of fourth of four escarpments. Elev. $1545 \mathrm{~m}, 05^{\circ} 23.083^{\prime} \mathrm{N}$, $059^{\circ} 58.550^{\prime} \mathrm{W}$. Dense forest on sandstone and peat, with Euterpe, Clusia, and 

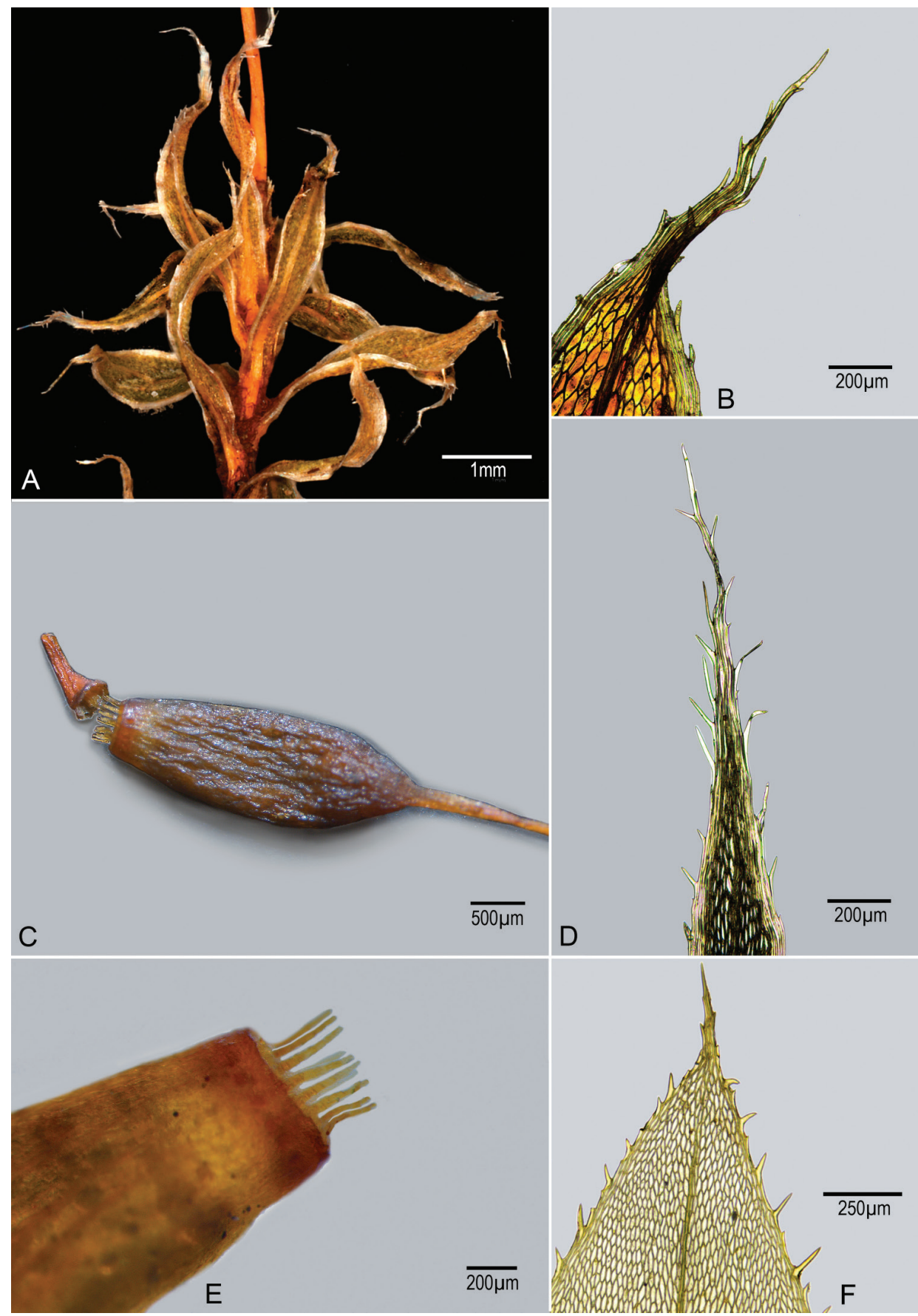

Figure I. Brachymenium ayangannensis H.Rob. \& G.K.Golinski. A Leafy stem showing distorted leaves B distal part of leaves, showing well-developed pale margin and spiniform teeth on both margin and long-acuminate tip $\mathbf{C}$ remoistened erect capsule showing partially detached short-rostrate operculum D B. perspinidens (Broth.) H.Rob. \& Golinski, distal part of leaf of holotype (from H) E tip of capsule mounted in Hoyer's solution showing short exostome and lack of well-developed endostome. The photographs were taken using a Leica DM4B Compound microscope, using a $5 \times$ objective. 
Brocchinia. Sporophytes green. On tree limb. H.D. Clarke 9551 with R. Williams, C. Perry, E. Tripp \&J. Kelly (US).

The peristome teeth of the new species have proven extremely fragile, possibly because of the radiation treatment.

The spiniform teeth of the leaf margin are distinctive, but the manner in which they occur on the acuminate apical extension is reminiscent of the illustration by Brotherus (1904: 557 fig. C; 1925: 367, figs C, D). This illustration has led to the comparison, but it proves to be somewhat inaccurate compared to the more recent illustration made from the type by Ochi (1972)

The African species is well illustrated by Ochi (1972), but the type from Helsinki has been borrowed not because of doubts of relationship so much as to insure that the two species are not the same. The principle difference is the absence of spinose teeth extending on to the apical acumination of the leaf. Nevertheless, there is no doubt the two are close, and the African species was placed in Bryum only because there was no sporophyte to indicate otherwise. A important point derived from the Ochi study is that none of the species in typical Bryum have spinose marginal teeth, all with such teeth are in what is now in the Brachymenium, Rhodobryum relationship. On the basis of the evident relationship between the African and Guyana species, the following transfer of the African species is provided.

\section{Brachymenium perspinidens (Broth.) H.Rob. \& G.K.Golinski, comb. nov.} Figure 1D

Bryum perspinidens Broth., Bot. Jahrb. Syst. 24: 246. 1897. Britische Ostafrika, Seengebiet: Ru- Nssóro, 3300-3600 m (Uganda: Ruwenzori, heather forest 10-12000'), Scott Elliot 266, Sterile. Rhodobryum perspinidens (Broth.) Pócs, in Bizot \& Pócs, Acta Bot. Acad. Sci. Hungaricae 25: 257. 1979 [1980]. With record of species from Tanzania, also sterile. Ochi (1972) indicated the species was rather an oddity in Bryum Hedw. subgenus Rhodobryum Schimp. in which he placed it.

Notes. Placement of the new species in Brachymenium is based on the capsules being erect with an inner peristome being a low membrane lacking segments or cilia, the traditional distinctions of the genus. Recent DNA studies (Pedersen et al. 2003, Pedersen and Hedenas 2005; Cox and Hedderson 2003) indicate that species that have been placed in the genus Brachymenium are mostly in basal branches of the Bryaceae while Bryum species are more derived. According to such studies, the genus Brachymenium is more entangled phyletically with the genus Rhodobryum (Schimp.) Hampe, Linnaea 38: 663. 1874, a later established genus and Osculatia De Not., Mem. Reale Accad. Sci. Torino, ser 2, 18: 445. 1859 (Robinson 1965; Ochyra et al. 2018). A survey of the illustrations in Brotherus $(1904,1925)$ shows an additional trend in Brachymenium that is lacking in typical Bryum, conical to rostrate opercula such is seen in the new species. In fact, within the present definition of Brachymenium, fully rostrate opercula occur in another species recently collected in Guyana. 


\section{Brachymenium speciosum (Hook. \& Wils.) Steere.}

Figure 2

Notes. The latter species has been collected on a mountain near Ayanganna as indicated below.

Mt. Wokomung, Little Ayanganna, upper slopes of highest point of Mount Wokomunga massif. $5^{\circ} 5^{\prime} 8^{\prime \prime} \mathrm{N}, 59^{\circ} 50^{\prime} 32^{\prime \prime W}$. elev. $1525 \mathrm{~m}$. Tepui scrub forest on sandstone
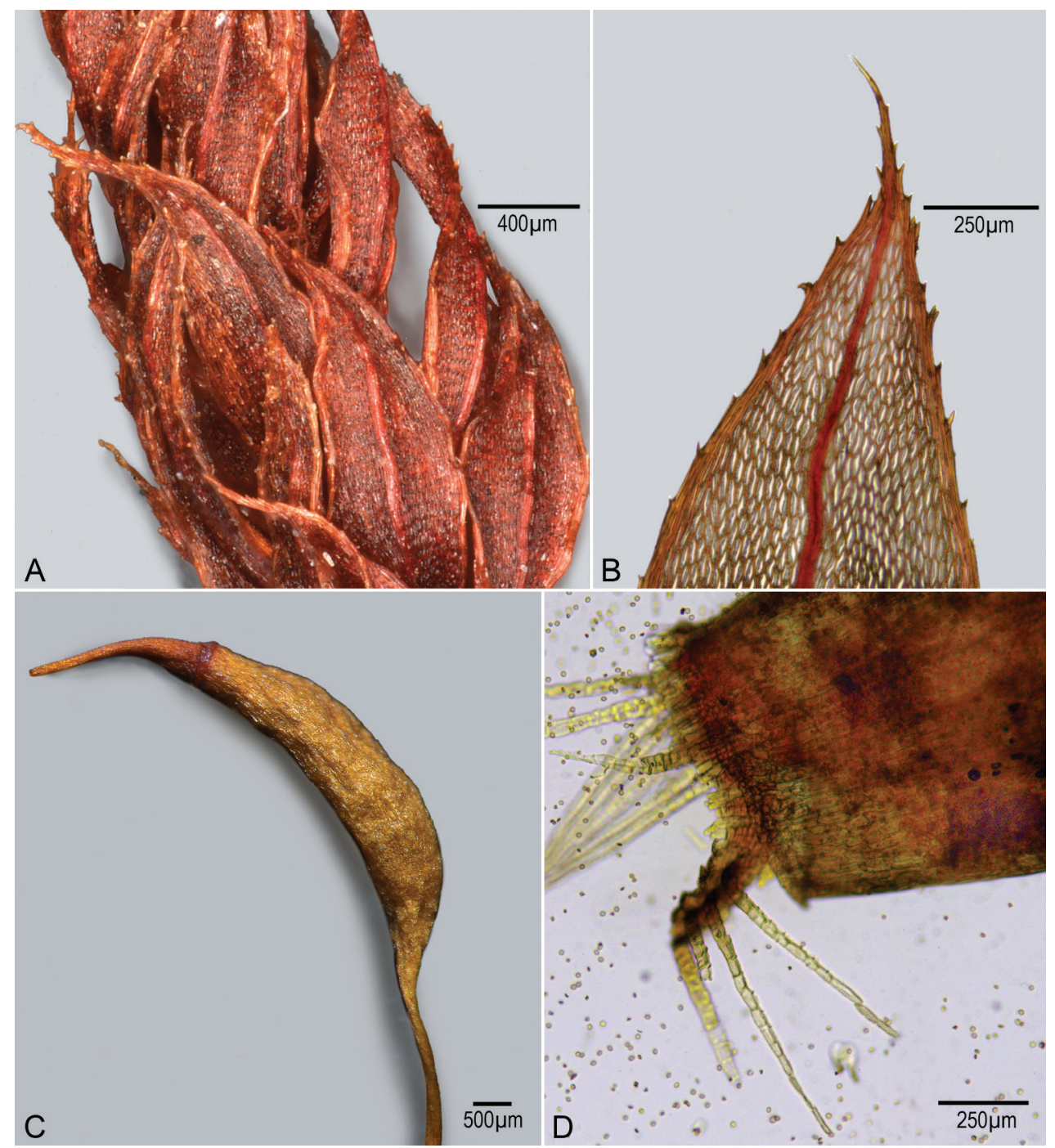

Figure 2. Brachymenium speciosum (Hook. \& Wils.) Steere. A Part of leafy stem showing distorted leaves B tip of leaf showing thickened margin with teeth on margin and upper and lower surfaces, some of these appearing as double teeth $\mathbf{C}$ capsule showing rostrate operculum $\mathbf{D}$ peristome teeth mounted in Hoyer's solution, showing elongate exostome teeth erect on one half and reflexed on other half, the latter showing endostome lacking cilia and segments. The photographs were taken using a Leica DM4B Compound microscope, $5 \times$ objective. 
and peat, with Schefflera, Clusia and Guadua. 5 July 2003, H.D. Clarke 10550, with R. Williams, C. Perry, J. Kelly, D. Gittens, S. Stern; Guiana. Mt. Wokomung, Little Ayanganna, upper slopes of highest point of Mount Wokomung massif. 5 $5^{\prime} 8 " \mathrm{~N}$, $59^{\circ} 50^{\prime} 32^{\prime \prime W}$. elev. $1525 \mathrm{~m}$. Tepui scrub forest on sandstone and peat, with Schefflera, Clusia and Guadua, elev. 1525 m. 5 July 2003, H.D. Clarke 10575, with R. Williams, C. Perry, J. Kelly, D. Gittens, S. Stern. Guiana. Mt. Wokomung, Little Ayanganna, upper slopes of highest point of Mount Wokomung massif. 5०4'53.1"N, 5950'26.1"W. elev. $1525 \mathrm{~m}$. Tepui bog on sandstone and peat, with Brocchinia, Bonnetia and Rapatea, elev. 1660 m. 6 July 2003, H.D. Clarke 10576, with R. Williams, C. Perry, J. Kelly, D. Gittens, S. Stern. Mt. Wokomung, area above third of four escarpments, $1 \mathrm{~km} \mathrm{NE}$ of Mt. Wokomung, 5०4'30"N, 59 51'15"W. elev. $1490 \mathrm{~m}$. dense forest on laterite, with Clusia, Euterpe and Licania, elev. 1490 m. 8 July 2003, H.D. Clarke 10802, with R. Williams, C. Perry, J. Kelly, D. Gittens, S. Stern. The material shows the additional feature of the species, the multistratose leaf margin with teeth on the margin and upper and lower surfaces. The species is otherwise reported from Suriname, Ecuador, and supposedly described from Jamaica (Maracaibo, Venezuela?)(Allen 2013; Steere 1948).

\section{Acknowledgements}

We thank Eric Schuettpelz, Chair of the Department of Botany, NMNH, for generously allowing us to use his lab and for providing ongoing support of our work on the bryophytes. H. David Clarke collected the specimens of Brachymenium ayanganna and B. speciosum while exploring the mountaintops of Guyana, funded by grants from National Geographic (Grant \#6622-990) and the Smithsonian Institution's Biodiversity of the Guiana Shield Program under the direction of Vicki Funk and Carol Kelloff. We appreciate the help of Sanna Laaka-Lindberg, Collection Coordinator of H Bryophyte Herbarium (Helsinki), for providing the type specimen of Brachymenium perspinidens, and Alice Tangerini, resident artist in the Department of Botany, NMNH, for expertly constructing the plates. Our manuscript greatly benefited from a thorough review by Blanka Aguero and an anonymous reviewer.

\section{References}

Allen B (2002) Moss Flora of Central America, Part 2. Encalyptaceae-Orthotrichaceae. Missouri Botanical Garden Press, St. Louis, Missouri.

Allen B (2013) Brachymenium regnellii and Bryum leptotorquescens (Bryaceae) new to Suriname. Polish Botanical Journal 58(1): 237-243. https://doi.org/10.2478/pbj-2013-0024

Brotherus VF (1897) Musci africani. II. In: Engler A (Ed.) Beiträge zur Flora von Africa. XIV. Botanische Jahrbücher fur Systematik, Pflanzengeschichte und Pflanzengeographie, 24: 232-284. 
Brotherus VF (1904) 219 Lieferung, Bryaceae, Leptostomaceae, Mniaceae, Rhizogoniaceae und Aulacomniaceae. In: Engler A, Prantl K (Eds) Die natürlichen Pflanzenfamilien. I. TEIL, 3, Abteilung, Bogen 37 bis 39. Verlag von Wilhelm Engelmann, Leipzig, 577-624.

Brotherus VF (1925) Musci (Laubmoose) 1 Hafte. In: Engler A, Prantl (Eds) Die natürlichen Pflanzenfamilien, ed. 2. 10, 478 pp.

Cox CJ, Hedderson AJ (2003) Phylogenetic relationships within the moss family Bryaceae based on chloroplast DNA evidence. Journal of Bryology 25(1): 31-40. https://doi. org/10.1179/037366803125002635

Kelloff CL, Funk VA, Alexander SN (2019) Smithsonian Plant collections, Guiana Shield. 1985-2014, Biological Diversity of the Guiana Shield Collections. Smithsonian Scholarly Press, Washington, DC. https://doi.org/10.5479/si.1938-2812.110

Ochi H (1972) A revision of African Bryoideae, Musci (First Part). J. Faculty of Educ. Tottori University 23(1): 1-126.

Ochyra R, Plášek V, Bednarek-Ochyra H (2018) Osculatia-an earlier name for a segregate of Bryum (Bryaceae, Bryophyta). Acta Musei Silesiae. Scientiae Naturales 67(1): 71-79. https://doi.org/10.2478/cszma-2018-0006

Pedersen N, Hedenas L (2005) Taxonomic and Nomenclatural Implications of Phylogenetic Studies of the Bryaceae Based on Molecular Data and Morphology. The Bryologist 108(1): 123-128. https://doi.org/10.1639/0007-2745(2005)108[123:TANIOP]2.0.CO;2

Pedersen N, Cox CJ, Hedenas L (2003) Phylogeny of the Moss Family Bryaceae Inferred from Chloroplast DNA Sequences and Morphology. Systematic Botany 28(3): 471-482.

Robinson H (1965) Venezuelan bryophytes collected by Julian Steyermark. Acta Botanica Venezuelica 1(1): 73-83. https://www.jstor.org/stable/41740407 [D.]

Steere WC (1948) Contribution to the bryogeography of Ecuador: A review of the species of Musci previously reported. The Bryologist 51(3): 65-167. https://doi.org/10.1639/00072745(1948)51[65:CTTBOE]2.0.CO;2 